\title{
The Non-Han in Socialist Cinema and Contemporary Films in the People's Republic of China
}

\section{Vanessa Frangville}

Translator. Elizabeth Guill

\section{(2) OpenEdition}

\section{Journals}

Electronic version

URL: http://journals.openedition.org/chinaperspectives/5877

DOI: 10.4000/chinaperspectives.5877

ISSN: 1996-4617

\section{Publisher}

Centre d'étude français sur la Chine contemporaine

\section{Printed version}

Date of publication: 4 June 2012

Number of pages: 61-69

ISSN: 2070-3449

\section{Electronic reference}

Vanessa Frangville, "The Non-Han in Socialist Cinema and Contemporary Films in the People's

Republic of China », China Perspectives [Online], 2012/2 | 2012, Online since 30 June 2015, connection on 28 October 2019. URL : http://journals.openedition.org/chinaperspectives/5877 ; DOI : 10.4000/ chinaperspectives.5877 


\title{
The Non-Han in Socialist Cinema
}

\section{and Contemporary Films}

\section{in the People's Republic of China}

\author{
VANESSA FRANGVILLE
}

\begin{abstract}
The following article places in context cinematographic representations of the non-Han during the socialist and contemporary eras of the People's Republic of China. These two periods are characterised by the prolific production and distribution of films featuring non-Han characters and by the wealth of subjects they deal with. The aim is therefore to shed light on the analysis of contemporary productions and to understand how they coexisted with the promotion of socialist films in the first decade of the twenty-first century.
\end{abstract}

KEYWORDS: minzu, non-Han, socialist cinema, contemporary cinema.

n April 2011, the town of Dali in Yunnan province inaugurated its "Museum of Rural Film" (nongcun dianying lishi bowuguan 农村电影历史博物馆). Proud of its cinematographic history, the town council featured a selection of fairly specific films: the shaoshu minzu pian 少数民族片or "films on minority minzu" made between 1950 and 1980. (1) Rather than an homage to rural film, however, this selection glorified the productions of so-called socialist cinema, the narrative and aesthetic pillars of which were the region's non-Han populations. The creation of the museum is related to two current trends, the celebration of the cinematographic tool and the glorification of an idealised revolutionary past. Indeed, the seventh art is fertile ground both in commercial and tourism terms, and it is a particularly effective propaganda tool for a national and international audience. The panegyric of national production is a means of maintaining a form of control over an industry that has experienced accelerated privatisation and transnationalisation of funding since 2000. (2) The Chinese authorities have therefore actively promoted the cinema in recent years, in particular with the opening in 2005 of an enormous "Museum of Chinese Cinema" (Zhongguo dianying bowuguan 中国电 影博物馆) in Beijing and a local and national cinema theme park (Chang Ying shijicheng 长影世纪城) in Changchun. Moreover, by integrating a cinema museum into regional circuits, the municipal authorities in Dali are contributing to another booming industry: tourism with a nationalist flavour. In this way, the non-Han are integrated into both "ethnic tourism" (minzu lüyou民 族旅游) and "red tourism" (hongse lüyou 红色旅游). ${ }^{(3)}$

It is against this background, therefore, that socialist films on the nonHan, like those of the new Dali museum, have been re-edited and screened numerous times since the early 2000s. Collections entitled "red films" (hongse dianying 红色电影) and "old classic films" (lao dianying jingdian 老电影经典) offer versions subtitled in English and Mandarin, sometimes simplified, technically enhanced, or remastered in colour. ${ }^{(4)}$ Eagles Brave the Storm (Bao fengyu zhong de xiongying, 1957, Wang Yi), which pays homage to the solidarity of Tibetans and Han soldiers during the Long March, was re-edited in 2007. Two spy films, Visitors on the Ice Mountain (Bingshan shang de laike, 1963, Zhao Xinshui) and The Caravan (Shanjian lingxiang mabang lai, 1954,Wang Weiyi), were re-screened as TV serials on the biggest national channels in 2006 and 2010. Lastly, Third Sister Liu (Liu sanjie, 1961, $\mathrm{Su} \mathrm{Li}$ ), which combines romance and class struggle amongst the Zhuang, is one of the most widely readapted films in terms of reworkings, and has also been remade for the cinema (The Singing Fairy, Xunzhao Liu sanjie, 2009, Zhu Feng) and turned into a musical show for tourist sites (Impression Liu sanjie, directed by Zhang Yimou). This renewed interest in the non-Han on the big screen was also characterised by the abundance of new productions in the 2000s, with more than 50 films made between 2000 and 2007. ${ }^{(5)}$ In

1. The translation into European languages of the word minzu民族 has varied in meaning over the last six decades: nation, race, nationality, ethnicity, and more recently, the voluntary absence of a translation. For further discussion of the concept of minzu and its ambiguity, see Joël Thoraval, "Le concept de minzu est-il obscur ? À propos du débat sur la notion de 'minzu' dans les années 1980 " (Is the concept of minzu obscure?), On the debate on the idea of "minzu" in the 1980s, Bulletin de sinologie, no. 65, March 1990, pp. 24-41. Concerning the placing in historical context of the different meanings of minzu, see Elena Barabantseva, Overseas Chinese, Ethnic Minorities and Nationalism: De-Centering China, London, Routledge, 2010.

2. The most effective means of control remains censorship. See Anne Loussouarn's article, "Death by a Thousand Cuts? How censorship stifles Chinese film industry," China Perspectives, no. 13, September-October 1997, pp. 20-25.

3. Concerning the relation between ethnic culture and tourism, see Tim Oakes, "The cultural space of modernity: Ethnic tourism and place identity in China," Environment and Planning D: Society and Space, vol. 11, no. 1, 1993, pp. 47-66. For an analysis of the promotion of the Communist cultural heritage with the aim of maintaining a national political identity, see Yiping Li et al.," Red Tourism: Sustaining Communist Identity in a Rapidly Changing China," Journal of Tourism and Cultural Change, vol. 8, no. 1-2, 2010, pp. 101-119.

4. The label "red" often applies to any kind of cultural production from the Maoist era, including songs, literary and poetic works, and cinema. More specifically, the category "red films" covers both war films and plots (jingxian pian 惊险片) that glorify the action of the People's Liberation Army (PLA) during the Maoist era. "Old classic films" refers more to comedies, picturesque films, and those dealing with "daily life" (shenghuo pian 生活片) during the same period. The two categories are, however, not exclusive, and it can happen that war films are attached to either.

5. Zou Huafen, "Ziwo, tazhe yu guojia - xinshiqi yilai woguo shaoshu minzu ticai dianying de shenfen biaoshu" (The self, the other and the nation - expression of identities in films on the minority minzu in the modern era), Xinan minzu daxue xuebao (Journal of the Minzu University of the Southwest), no. 10, 2008, pp. 135-140. 
2004, 12 of the 212 films produced in China featured non-Han characters, an annual figure judged "insufficient" in terms of percentage but one that remains the highest in the history of the cinema on the non-Han. ${ }^{(6)}$ At the same time, a great deal of academic research encouraged the production of new films on the non-Han, insisting on the need to preserve their cultures and open up new perspectives for the development of Chinese cinema. ${ }^{(7)}$

Cultural representations of minority minzu constitute a field of study that has been developed over the last 20 years. The key role of the "primitive" non-Han in the formation of a modern Han majority has been observed and widely documented. ${ }^{(8)}$ This dichotomy implies a hierarchisation of populations within the framework of Chinese national construction, often related to the domination of men over women. ${ }^{(9)}$ Moreover, cinema specialists have highlighted the "over-representation" of the non-Han and the processes of exoticising and homogenising an "internal Other." (10) Three major historic periods can be identified in the evolution of the representation of the non-Han: the years 1950-1966, also known as the "17 years" in Chinese (shiqinian 十七年), the era of the reforms in the late 1980s, and the end of the 1990s up until the present time, marked by the official entry of China onto the world political and economic stage. However, it has to be said that this latter period has not been systematically explored and that few studies place the various periods of film production featuring the nonHan into perspective. In an article on Tian Zhuangzhuang, Dru Gladney compares the films of the 1950-1960s to the director's first films set on the plains of Mongolia, Hunting Ground (Liechang zhasa, 1985), and on the Tibetan plateaux, The Horse Thief (Daomazei, 1986). ${ }^{(11)}$ Although these films are somewhat removed from modes of socialist representation, Han exoticism and ethno-centricism remain relevant in what proves to be, on the director's own admission, hidden stories on Han society. ${ }^{(12)}$ Kwai-Cheung Lo analyses the evolution of representations of the non-Han in the work of Tian Zhuangzhuang from the 1980s up until the production of Delamu (Chamagudao: Delamu, 2004), a documentary film that portrays non-Han inhabitants of the Tea Route in Yunnan. ${ }^{(13)}$ The researcher mentions certain technical and narrative innovations but also underlines the search for a "cultural other" that mirrors over-modernised Han society.

This research gives a brief glimpse (requiring further development) into the evolution of cinema featuring the non-Han and their representations at the beginning of the twenty-first century. The first decade of the century was characterised by two concomitant phenomena: the promotion of socialist films on the non-Han, and the mushrooming of new productions on the same theme. To what extent do the images of the non-Han in socialist and contemporary films interact, contradict, or complete each other? How do socialist representations of the non-Han, strongly coloured by an outdated ideology, fit in alongside the new films being made in contemporary China? Putting these two eras into perspective allows us not only to shed light on the analysis of contemporary representations but also to rethink those of the socialist years.

\section{The non-Han in the cinema of the "17 years": From "little sisters" to socialist subjects}

In its depiction of non-Han populations from the 1950s onwards, the cinema is one of the institutions that have closely followed the development of policies implemented by the CCP. (14) Indeed, the edification of a "new China" was mainly founded on propaganda, a communication strategy of which the cinema is a key element. The Central Department of Propaganda (zhongxuan bu 中宣部) set up in 1949 ensured that "cultural productions were adapted to the revolutionary machine," and this included film production. ${ }^{(15)}$ The creation of a cinematographic genre of minority minzu in the first part of the 1950s coincided with the nationalisation of the film studios (completed in 1953), as did the launch of the ethnic classification project and the opening of academic institutions for the non-Han. This genre, the shaoshu minzu pian, can be defined by the placing of the action in a non-Han context: the "daily life" of the non-Han protagonists is explored, emphasising certain aspects as diverse as clothing, kitchen utensils, festivities, costumes, and social organisation, seen as typical. The genre also includes tales inspired by nonHan stories and legends, in which membership of a minzu is placed to the fore by aesthetic or narrative means. Between 1950 and 1965, 50 or so productions belonged to this new genre, including more than 30 between 1956 and 1965, that is to say 6 percent of national film production, a not insignificant figure for a genre still in its infancy. ${ }^{(16)}$ Between 1950 and 1955, films on minority minzu belonged to another cinematographic genre, that of "war films" in which stories were told of the courage and solidarity of the Han and non-Han in the struggle against enemies of the regime, on the plains of Mongolia, the mountains of Xinjiang, and other highly strategic frontier regions. After the Hundred Flowers Movement in 1956, various measures applied to the film industry expanded the range of films on the minority minzu to include fiction (gushi pian 故事片), musical films (gechang pian 歌唱片), and picturesque films (fengguang pian 风光片), adding variety to this new genre in terms of both style and content. Certain of these works became essential classics of Chinese cinema, combining technological innovation (including the first colour film to be made in China) and aesthetic quality.

6. People's Daily online (Renmin wang), 15 November 2005.

7. Rao Shuguang, Zhongguo shaoshu minzu dianying shi (History of films on the minzu Chinese minorities), Peking, Zhongguo dianying chubanshe, 2011. Zou Huafen, Minzu shenfen yu xingbie biaoshu - Xin shiqi shaoshu minzu ticai dianying zhong de nüxing xingxiang (Ethnic identity and representation of gender - Images of women in films on minority minzu in the modern era), Shanghai, Huadong shifan daxue, 2008. Li Ershi, "Shiqinian dianying yu shaoshu minzu ticai" (The cinema of the "17 years" and the subject of ethnic minorities), in Lu Hongshi (ed.), Zhongguo dianying: miaoshu yu chanshi (Chinese cinema: Description and interpretation), Beijing, Zhongguo dianying chubanshe, 2002, pp. 305-51.

8. Stevan Harrell, Ways of Being Ethnic in Southern China, Seattle (Washington), University of Washington Press, 2001; Ralph A. Litzinger, Other Chinas: The Yao and the Politics of National Belonging, Durham (North Carolina), Duke University Press, 2000.

9. Dru C. Gladney, Dislocating China: Reflections on Muslims, Minorities and Other Subaltern Subjects, London, Hurst \& Cie, 2004; Louisa Schein, Minority Rules: The Miao and the Feminine in China's Cultural Politics, London, Duke University Press, 2000.

10. Paul Clark, Chinese Cinema: Culture and Politics Since 1949, Cambridge, Cambridge University Press, 2005, Chapter 4; Paul Clark, "Ethnic Minorities in Chinese Films: Cinema and the Exotic," in East West Film Journal, vol. 1, no. 2, June 1987, pp. 15-31. Chris Berry and Mary Farquhar, China on Screen: Cinema and Nation, New York, Columbia University Press, 2006, p. 169. Zhang Yingjin, "From 'Minority Film' to 'Minority Discourse': Questions of Nationhood and Ethnicity in Chinese Cinema," in Sheldon Hsiao-peng Lu (ed.), Transnational Chinese Cinemas, Identity, Nationhood, Gender, Honolulu, University of Hawaii Press, 1997, pp. 81-104.

11. Dru C. Gladney, "Tian Zhuangzhuang, The 'Fifth Generation' and 'Minorities Films' in China: A Review Essay," Public Culture, 1995, vol. 8, no. 1, pp. 161-175.

12. Georges Semsel et al. (ed.), Chinese Film Theory, A Guide to the New Era, Westport, Connecticut, Praeger Publishers, 1990, pp. 31 sq.

13. Kwai-Cheung Lo, "Two Moments of Ethnic Representations in Tian Zhuangzhuang's Minority Films," Journal of Chinese Cinemas, vol. 3, no. 3, 2009, pp. 231-247.

14. The few films on the non-Han made before 1949 were not placed in a specific production category before 1949: Berry, China on Screen, op. cit., p. 181.

15. The zhongxuan bu took over from the Bureau of Propaganda created in 1922 within the propaganda system (xuanchuanxitong 宣传系统) set up by the CCP. David Shambaugh, "China's Propaganda System: Institutions, Process and Efficacy," The China Journal, no. 57, 2007, pp. 25-58. Anne-Marie Brady, Marketing Dictatorship: Propaganda and Thought Work in Contemporary China, Lanham, Rowman and Littlefield, 2008.

16. Berry, China on Screen, op. cit., p. 181. 
Like all films of the time, they were aimed at spreading and encouraging "the socialist spirit" by including groups on the sidelines of Chinese society and territories. The use of unambiguous "typical characters and events" was the hallmark of the cinema of the 1950-1960s, ensuring the effective reception of political messages by all. ${ }^{(17)}$ But they also played a part in the stabilisation of relations between Han and non-Han and in the definition of a national identity, at a time when the migration of Han populations towards outlying areas was organised on a grand scale. The image of minority minzu who were welcoming and benevolent towards the Han was widely diffused, whilst at the same time the idea was intended to educate people on the particularities of each minzu. Apart from several non-Han actors and technicians trained by regional studios, the film industry was run by Han. These representations were therefore seen through the often urban, educated, and masculine prism of the Han, leaving no room for non-Han subjectivity. ${ }^{(18)}$ Similarly, the target audience was mainly Han. The films were always made or dubbed in Mandarin, and the presence of fictional Han characters, was, with very few exceptions, systematic. The omnipresence of the Han therefore appears as a significant act of "surveillance" or domination of the observed by the observer. Moreover, whilst the Han always appear as a culturally and geographically homogenous and indistinct minzu, the non-Han seem solely constructed around their membership of a place, adherence to cultural practices, and their ethnicity. This highlighting of the differences between Han and nonHan, and the specific traits of each non-Han group is another characteristic of the minority minzu genre of films. The work of anthropologist Dru Gladney, one of the first to deconstruct non-Han images, reveals the relationships between national and ethnic identities in China. Placing his work on the Hui in the field of subaltern studies and as an inheritor of Edward Said's orientalism, Gladney draws attention to the process of constructing the Chinese nation in the Han/non-Han dichotomy. Indeed, images of the nonHan in socialist cinema are constructed in binary opposition to the Han: archaism and modernity, ignorance and knowledge, weakness and power. The simplification of the relationships between $\mathrm{Han}$ and non-Han rests on a naturalisation of the characteristics of each group, presented as homogenous. Minority minzu were presented as backward, fragile, and unable to free themselves or meet their own needs, and with no control over their fate, whilst the Han were educated, modern, able to defend and protect the weak, and devoted body and soul to the great socialist cause. These stereotypes standardise a hierarchic relationship that places the Han in the position of guides to their non-Han "little sisters," a model that Gladney summarises in the term "internal colonialism." (19) The three metaphors of the Han's civilising project suggested by Stevan Harrell - children (education), women (gender), and the elderly (history) - come fully into their own in these films. ${ }^{(20)}$ All these representations contribute, in Frantz Fanon's terms, to the "devaluing of the history" of the minorities by the Han, and promote the image of a rosy future under their authority. (21) The loyalty of the non-Han to their "big Han brothers" is unshakeable, and the fate reserved for traitors most unenviable. The supposed backwardness of the nonHan on the evolutionary scale is perceived as negative and incompatible with a prosperous society. It finds its resolution in commitment to the revolutionary struggle under the protection of the Han.

The classic themes of socialist cinema on the non-Han can be seen in recently re-edited or re-adapted films. The Caravan is set in the Yunnan heights, where the PLA has grouped to protect Hani and Miao villages from enemy attack and to patrol the frontier. The story mainly centres on the hijacking by Nationalist traitors of a caravan carrying salt and other necessi- ties of daily life sent by the government and a love story between Daiwu, head of the Miao frontier guards who is helping the Han soldiers, and the lovely Miao woman Lanbang. The story of Visitors on the Ice Mountain centres on the same relationship between treachery and romance. Amir, a young Uyghur who has joined the PLA, is troubled by the presence of $\mathrm{Cu}$ lendam, who claims to be his childhood sweetheart. He gradually realises that the young woman has been sent by reactionary enemies to spread trouble in the region, usurping the identity of the real Gulendam. Amir becomes suspicious when the young woman is incapable of recognising a song they sang when they were children. The reunion of the lovers through song is a feature it shares with Five Colden Flowers (Wu duo jinhua, 1959, Wang Jiayi) which follows the adventures of the young Bai, A Peng, and Jinhua. Although they promise to meet again during the Third Month Fair (sanyue jie 三月街), one of the Dali region's most important events, Jinhua cannot be found. A Peng leaves to look for her and meets two Han on the road who are in charge of collecting the region's songs. (22) With their help and following the many misunderstandings that cheerfully pepper the story, A Peng and jinhua are finally reunited. Eagles of the Steppe (Caoyuan xiongying, 1964, Ling Zifeng) features two Kazakh veterinarians, Ali and Amina, newly qualified in the capital, who are returning to their native Xinjiang. Their mission is to eradicate the diseases that are weakening the flocks on the surrounding steppes. Once there, they are confronted with Kader, who despite his lack of education proves more skilled in treating the animals. All three end up cooperating successfully, with Kader discovering the works of Mao, lent to him by Amina and Ali after they recognise Kader's professional skills.

The minority minzu, despite their function of promoting the virtues of the Han, give Han film-makers and spectators an opportunity to penetrate a world seen as foreign and to satisfy their curiosity about them. The settings precede the characters in these films, which open onto the wild, infinite landscapes of Yunnan and Xinjiang. These approaches underline the physical marginality of the non-Han, who live in distant, hard-to-reach regions beyond the mountains, forests, and plains. Moreover, they allow the spectator to identify the non-Han with their environment. The young Jinhua in Five Golden Flowers sings of her love for A Peng in an idyllic country setting. Sitting by the water, she looks at her perfectly clear reflection on which the camera suddenly focuses. This movement has the effect of plunging the spectator into confusion, since he does not know whether he is seeing the character or her reflection. Jinhua is literally at one with the exotic, wild environment with which she is identified. The whole of the following scene in which she sings with A Peng plays on an aesthetic that envelopes the characters in the landscapes. Moreover, an identical presentation of deserted landscapes in the opening and final credit sequences of films also creates a solid

17. Paul Clark, Chinese Cinema, op. cit., p. 95

18. Esther Yau, "Is China the End of Hermeneutics? Or, Political and Cultural Usage of non-Han Women in Mainland Chinese Films," in Diane Carson et al. (ed.), Multiple Voices in Feminist Film Criticism, Minneapolis, University of Minnesota Press, 1994, pp. 280-292.

19. Dru C. Gladney, "Internal Colonialism and the Uyghur Nationality: Chinese Nationalism and its Subaltern Subjects," Cahiers d'études sur la Méditerranée orientale et le monde turcoiranien- Les Ouïgours au xxe siècle, 1998, no. 25, pp. 46-63.

20. Introduction by Stevan Harrell (ed.), Cultural Encounters on China's Ethnic Frontiers, Seattle, University of Washington Press, 1995.

21. Frantz Fanon, Les Damnés de la Terre (The Wretched of the Earth), Paris, La Découverte, 2002 [1961], p. 201.

22. The collection and transcription of songs in rural areas (whether Han or not) was a common practice in China under the Imperial governments, taken up again in the Republican era under the Communist regime. Sabine Trébinjac, Le pouvoir en chantant (Power in Song) (volumes 1 and 2), Nanterre, Société d'ethnologie, 2000 and 2008. 


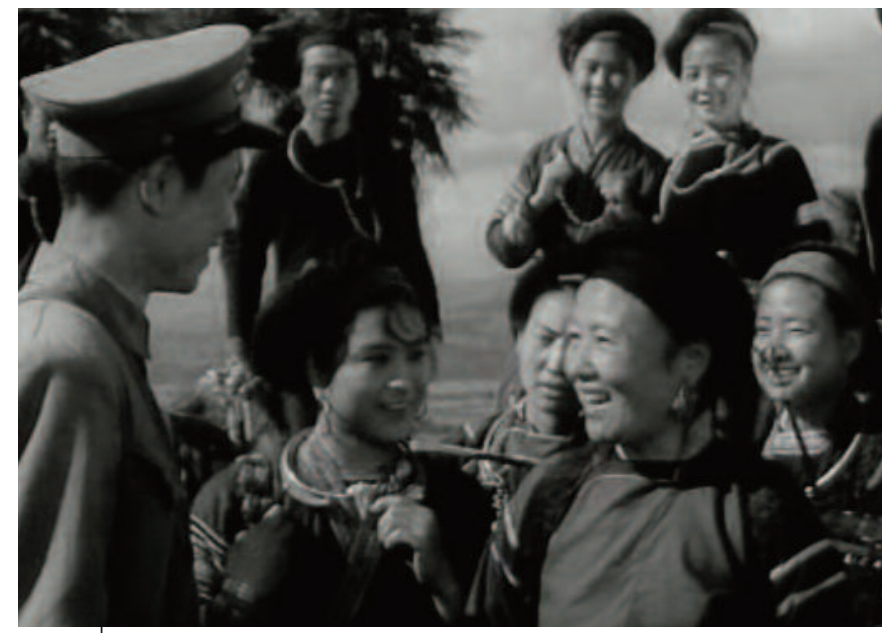

The Han officer is warmly welcomed by all the non-Han women of the village. Extracts from The Caravan, 1954

link between the non-Han and their environment, which remains unchanged despite the long chain of events. The primitiveness of the non-Han is also emphasised by the suggestion of their affinity with animals. In Eagles of the Steppe, the young Kazakhs never cease busying themselves with animals with a passion very similar to that of the Han doctors in The Caravan for the Miao and Hani villagers. The exaggerated expression of the emotions of non-Han characters in dance and song presents an image of them that is far removed from the seriousness of the Han. Even the sombre and violent plot of Visitors on the Ice Mountain has scenes of songs and improvised concerts at its centre.

Moreover, the non-Han women are the only female characters in the films (besides several extras clad in neutral, severe medical coats). For Dru Gladney, an "internal orientalism" characterises the relationships between Han and non-Han symbolised by the metaphor of modern man dominating primitive woman. ${ }^{(23)}$ The cultural and political superiority of the Han is therefore highlighted by the exaggerated femininity of the many non-Han young women surrounding them, as Harriet Evans observes in her study of revolutionary propaganda posters. (24) Upon their arrival in non-Han villages, the Han in The Caravan are warmly welcomed by young, well-dressed women whose small stature accentuates the stature of the Han. However, it must be said that the representations of non-Han women are not limited to their erotic aspect. Doubly oppressed by their status as women in a "backward" non-Han society, the manner in which their emancipation is constructed and transmitted symbolises the move to the prosperity of socialism. The five young women named jinhua who are met by A Peng are active contributors to the Great Leap Forward. Amina is even superior to Ali inasmuch as she adopts a more humble stance towards the country doctor and takes it upon herself to educate him by giving him the works of Mao. Similarly, it must be mentioned that the presence of young non-Han men plays a not insignificant role in highlighting the physical and intellectual qualities of the Han. These characters, touching in their naivety and the spontaneity of their reactions, which are sometimes even comic, often play secondary, but indispensable roles in the progress of the PLA in unknown and dangerous territory. They can even show off their prowess as A Peng does during the contests at the fair, but they never enter into competition with the Han. Their unimposing physique, often made to seem feminine by the sophistication of their costumes and brightly coloured clothing and their childish behaviour, does not allow them to rival the strength and purposefulness of the Han. Lastly, the fragility of the non-Han characters is expressed by the absence of at least one of their parents. Daiwu only has his mother, whilst his beloved lives alone with her father. Jinhua only has her grandfather, and the real Gulendam has lost her mother and has long been separated from her father. The metaphor of the family reinforces the idea of a domestic intrigue that brings Han and non-Han closer together and positions the Han as a patriarch or substitute educator.

Paul Clark distinguished between the films on the minzu in the north, with their dark, violent plots, and those on the minzu in the south, which are colourful, happy romances. ${ }^{(25)}$ Contrary to what this categorisation might lead us to suppose, a close relationship between two young non-Han people leavens the narrative of the films, even for the protagonists of Visitors on the Ice Mountain. Spy stories can also serve as a screenplay in Yunnan, as in The Caravan. The characters engage in singing whilst they declare their love, a seduction practice free from all moral constraints often attributed to the non-Han. The films conclude on the reunion of two lovers, their reciprocal commitment equal only to their commitment to the socialist cause. These representations are in strong contrast to the de-sexualised heroes of socialist cinema on the Han, who are usually unattached and whose conversation with their friend of the opposite sex is restricted to the revolutionary struggle. ${ }^{(26)}$ The overfeminisation of jinhua contrasts strongly with, for example, the Han heroine in another socialist cinema classic, The Women's Red Detachment (Hongse niangzijun, 1961, Xie jin), also set in exotic landscapes, on the island of Hainan. The control and even absence of any sexuality is considered in socialist rhetoric as a condition for progress and modernisation. All representations of sexuality, including amorous exchanges, lead to the character being assimilated into the primitive and non-civilised; therefore no romance is clearly defined, although Ali's defiance of Kader suggests jealousy not only over the question of his medical skills but also of his relationships with Amina.

The minority minzu, figures of otherness in relation to which the Han shape their own identity, are nonetheless called upon to conform to a national model. The religious nature of the big Bai festival in March, or Guanyin Market (guanyinshi 观音市), is completely avoided. (27) Originally an homage to the Goddess Guanyin, the festival takes on a completely different meaning in the presence of the PLA soldiers. Bringing together as it does many of Yunnan's minority minzu in a lively, happy atmosphere, it constitutes an ode to national unity. Winner of a horse race during which red flags must be picked up, A Peng receives a gun from a soldier as a prize. The symbolic participation of the Miao in the socialist struggle is therefore rewarded by the Han, who entrust him with the job of defending the nation. The festivities have been invested with new meaning, giving the Han a decisive role in the event. They serve to regulate and channel aspects of local life at the same time as providing a means of promoting the regime. ${ }^{(28)}$ Although the films emphasise the differences between

23. Gladney, Dislocating China, op. cit., pp. 90 sq.

24. Harriet Evans (ed.), Picturing Power in the People's Republic of China, Posters of the Cultural Revolution, Rowman \& Littlefield, 1999, pp. 63 sq.

25. Paul Clark, "Ethnic Minorities in Chinese Films," art. cit., pp. 20-21.

26. Emily Honig, "Socialist Sex:The Cultural Revolution Revisited," Modern China, 2003, vol. 29, no. 2, pp. 143-175. Harriet Evans, Women and Sexuality in China: Dominant Discourses of Female Sexuality and Gender since 1949, New York, Continuum, 1997, pp. 7 sq:; Bai Ge, 1966-1976: Zhongguo baixing shenghuo shilu (Annals of the life of the ordinary Chinese people: 1966-1976), Beijing, Jinguan jiaoyu chubanshe, 1996, p. 227.

27. Wu Xiulin, "Shilun 'sanyue jie' dui Dali jingji wenhua de yingxiang" (On the impact of "sanyuejie" on the economic culture of Dali), Dali xueyuan xuebao (Journal of the Dali Institute), no. 11, 2007, pp. 35-37.

28. For further information on the promotion of local festivals by the CCP, see U. Bulag's study on the cult of Lake Kökönuur in Inner Mongolia and the work of R. Litzinger on the folk activities of the Yao and the vigilance of the Party cadres in this respect: Uradyn Bulag, The Mongol at China's Edge: History and the Politics of National Unity, London, Rowan \& Littlefield, 2002. 

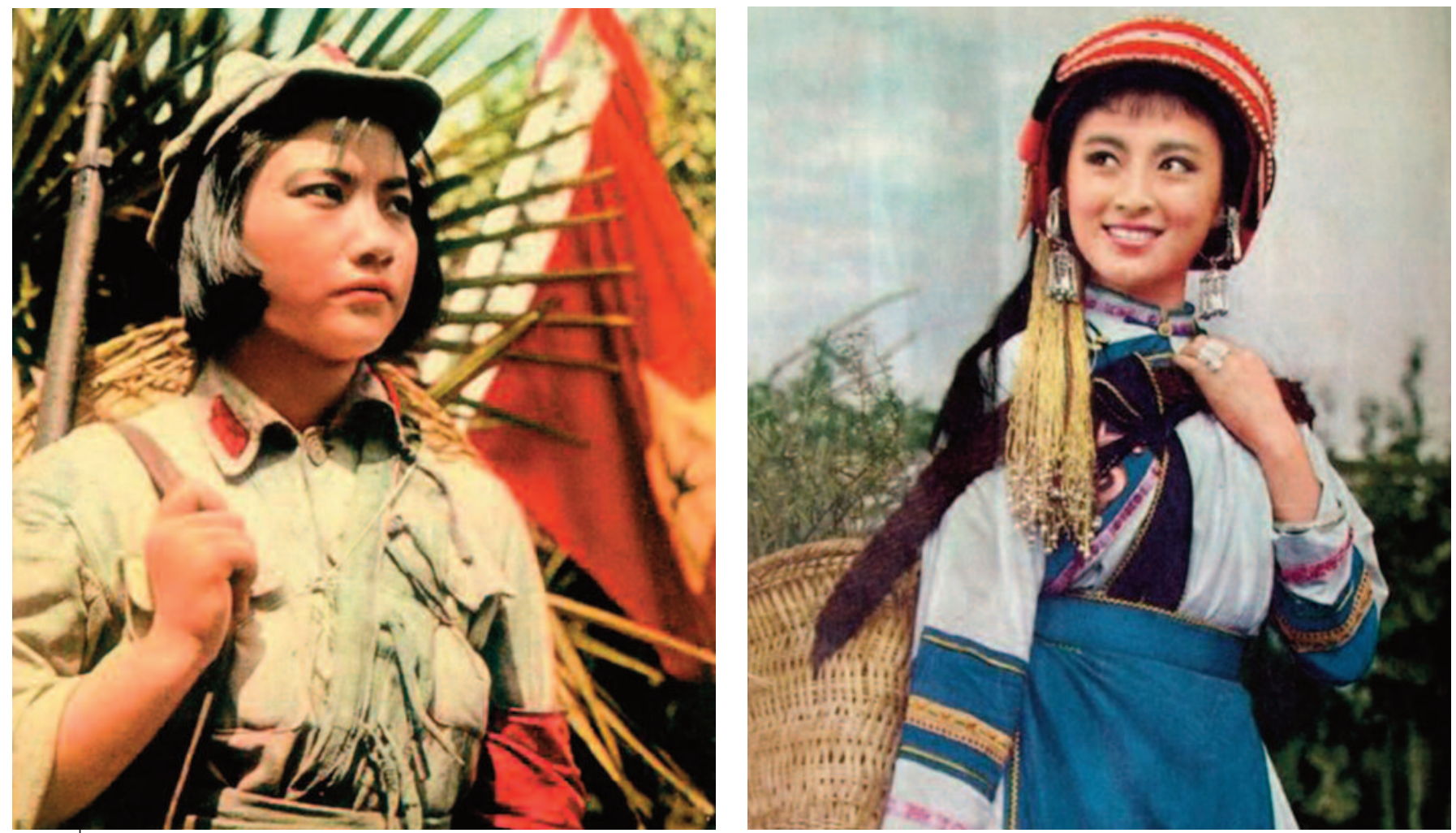

Contrasting figures of Du Qinghua (left) and Jinhua (right) in 1959.

Extracts from The Red Detachment of Women (Tianma Film Studio, 1961) and Five Golden Flowers (Changchun Film Studio, 1959).

Han and non-Han, they impose a standardised vision of the members of the Chinese nation. They illustrate the uniformity of the historic narrative (the "liberation" of the non-Han, the introduction of the reforms and their impact) and of cultural forms (rites, festivals, heritage) in the "New China." In short, socialist films on the minority minzu contribute to building up a style or "national aesthetic" (minzu fengge 民族风格) that gives China a cultural and political identity at the national and international level. (29) Images of romantic, exotic minorities contribute to a strategy of auto-orientalism in the construction of a new China, offering a negotiation between modernity and tradition that is warmer and less rigid than in films that only feature the Han. We must, however, qualify Paul Clark's view of the role of these films as a substitute for Western exoticism. ${ }^{(30)}$ As Zhang Yingjin points out, it is less a question of "satisfying the desire for the foreign" than of the portrayal of the non-Han as a variety of stereotypes that make it easier for them to fit into the socialist mould. (31) Paul Clark accepts, moreover, the essential function of the non-Han in the exploration of subjects that are difficult to tackle in a Han context. ${ }^{(32)}$ Moreover, and more obviously, the films establish power relationships that emphasise the "natural" and "historic" authority of the Han over the non-Han, a vision that is fully expressed nowadays in the Development of the West project (xibudakaifa 西部大开发) implemented at the beginning of the century.

\section{The non-Han in contemporary cinema: Overturning and reformulating stereotypes}

The 2000s testified to renewed popularity for films about minority minzu, through the promotion of socialist films, but also and more forcefully through the production of contemporary films. A genre that seemed to have disappeared in the meanders of the cinema's institutional reforms was resuscitated by a set of economic and political measures. ${ }^{(33)}$ These include the substantial financing of production by the state and the active promotion of films on the non-Han within the framework of official festivals (aimed at domestic and international audiences), which play a dominant role in the renewal of films on the non-Han. At the end of 2011, the "online week of Chinese cinema," initiated by Radio China International and the Film Bureau on the Chinese Films Online site, offered a choice of ten films and documentaries, six of which featured non-Han characters. ${ }^{(34)}$ The second Beijing International Film Festival (BJIFF), held in April 2012, announced a privileged place in its program for films on the non-Han. ${ }^{(35)}$ Press articles and academic contributions also emphasise the development of films on the non-Han as a "cultural strategy" aimed at "giving a boost to the Chinese film industry" and entering the world economic market of the twenty-first century. Arguing that the present century is one of multiculturalism, Peng Huiyuan suggests placing the accent on the production of films on the non-Han in order to contribute to global cultural diversity as well as to "compete with Hollywood." (36) The splendid landscapes

29. Paul Clark, Chinese Cinema, op. cit., pp. 101 sq. See also, Zhang Yingjin, "Minority Discourse," art. cit., pp. 81 sq.

30. Paul Clark, Chinese Cinema, op. cit., pp. 95 sq.

31. Zhang Yingjin, "Minority Discourse," art. cit., p. 89.

32. Paul Clark, "Ethnic Minorities in Chinese Films," art. cit., p. 20

33. Zhang Xiaoming, "From Institution to Industry: Reforms in Cultural Institutions in China," International Journal of Cultural Studies, vol. 9, no. 3, 2006, pp. 297-306 ; Ying Zhu, Chinese Cinema during the Era of Reform: The Ingenuity of the System, Westport, Praeger, 2003.

34. As part of a project known as "China in images," these films were available online on chinesefilms.cn

35. Xinhuanet.com, 8 February 2012.

36. Peng Huiyuan, "Shaoshu minzu ticai dianying fazhan de wenhua zhanlue yiyi" (The importance of the cultural strategy of the development of films on the minority minzu), Minzu yishu yanjiu (Studies of ethnic art), no. 3, 2009, pp. 80-85. 
of Yunnan, the deserts and breathtaking plateaux of Xinjiang and Tibet, and the mixture of exoticism and savagery attributed to the minority minzu lends itself to epic tales that attract audiences of all origins. At the same time, films on the non-Han contribute to formulating an identity that counters the "Americanisation" of Chinese culture. ${ }^{\left({ }^{37}\right)}$ Although the film industry on the non-Han continues to be largely dominated by the Han, new aspects are nonetheless present. The use of non-Han and often non-professional actors has become widespread, as have film-shoots and screenings in local languages (subtitled in Mandarin). In addition, the non-Han have entered into the history of Chinese cinema by getting behind the camera and making feature films whose success has travelled beyond China's borders, mainly as a result of more energetic promotion by the Government. (38)

The new representations of the non-Han that proliferated after 2000 are part of the continuation of the "cultural fever" (wenhuare 文化热) that characterised the post-Maoist years and propelled non-Han cultures to a new status in the second half of the 1980s. ${ }^{(39)}$ The cinema has not been excluded from this enthusiasm for minority populations, which was expressed in a more popular form in the 1980-1990s. But this movement must above all be placed in the context of a country whose industrialisation and urbanisation have accelerated beyond measure over the last 30 years. The modernisation project launched by Deng Xiaoping at the start of the 1980s has always placed the economic development of the PRC at its heart, to the detriment of the poorest populations and of the environment. The question of national identity also takes on another dimension at a time when China's influence on the international stage is continually growing along with the impact of globalisation on China.

In this context, the use of minority minzu is seen from a very different perspective from that of the socialist years. Contemporary films featuring the non-Han continue to attribute primitive, backward characteristics to them. It is always the spectator or a city-dwelling Han protagonist who sets out to meet them. The non-Han never leave the reclusive places where they live. These characteristics are no longer perceived as negative and in need of correction or eradication, however. On the contrary, the non-Han represent spiritual models for the Han, who suffer from the loss of a "primitive integrity." The apparent "over-modernity" of the Han is the source of their alienation, which is resolved by encounters with non-Han belonging to a "lost paradise" or a "golden age" of humanity. Moreover, the differences between Han and non-Han are no longer overcome through a socialist project but through a common history and national heritage. The class struggle and critique of the intellectual class, often very pronounced in films on the non-Han of the socialist period, are eluded through a panegyric of an ancestral China that has the power to give "a soul" to a modern Han society now turned towards the market economy. Moreover, the promotion of a harmonious society rests on a set of concerns that seem shared by Han and non-Han alike, but which are also universal problems: critique of consumerism and materialism that alter the individual, concern for preserving cultural and natural elements threatened by modernity, and the desire to affirm a national identity in a global era.

However, the dichotomy between Han and non-Han has not been completely effaced. The reversal of hierarchic relationships portrayed in these new representations has resulted in reality in the reformulation of Han domination and the reification of the non-Han. Moreover, the mystical nature of representations of the non-Han very often enables deflection of economic and political questions linked to the development of tourism, industrialisation, or the massive emigration of populations from the central areas to peripheral regions.

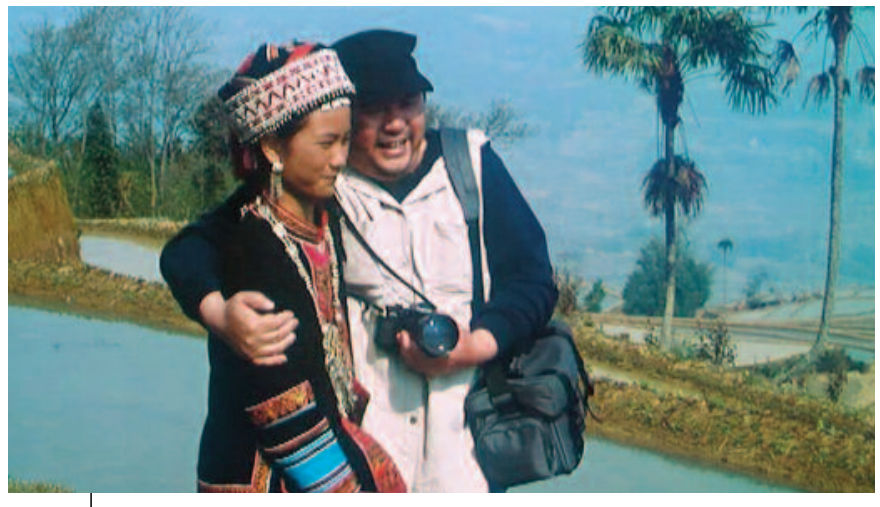

Ruoma, victim of the commercialisation of her body. Extract from When Ruoma was 17, Condor Han, 2002.

The heroine of When Ruoma was 17 (Ruoma de shiqi sui, 2002, Zhang Jiarui) is a young Hani girl who travels several kilometres every day to sell grilled corn-on-the-cob in town. Spotted by a Han photographer, A Ming, whose business is clearly going through a bad patch, she is asked to pose in a Hani costume with tourists in front of the region's magnificent landscapes. The young girl therefore travels through Yunnan's crop terraces on the back of the young city-dweller's motorcycle, inspired by a dream of going into a high building in town and taking the elevator, which he has promised to fulfil (obviously a metaphor for both modernity and upward social mobility). The Plain of Paradise (Tianshang caoyuan, 2002, Sai Fu and Mai Lisi) takes place in Inner Mongolia, in the Tenggelitala, which means "paradise" in Mongol. The story is told from the point of view of Huzi, who is recalling his childhood journey across the Mongol plains. Struck dumb after the loss of his parents, the Han child was taken in by Shergan, a former prisoner who met Huzi's father in prison, and his ex-wife, Baruma. Despite Huzi's difficulty in finding his place in this tormented family, and in spite of various acts of brutality that are foreign to him (the slaughter of a sheep, the hunting of a wolf, and Shergan's violence towards his wife), he gradually regains confidence in the adult world. Kekexili (Kekexili, 2004, Lu Chuan) follows a Beijing reporter, $\mathrm{Ga}$ Yu, who is investigating a non-official Tibetan patrol organised to protect the last antelopes in the Kekexili region (classed as a nature reserve since 1995). Involved in a violent struggle against poachers, the men penetrate deeper into this glacial desert that inspires both fear and fascination. Lastly, Ganglamedo (Ganglameiduo, 2006, Dai Wei) is the name of a popular Tibetan song and of a young girl who is particular good at performing it. (40) In the 1940s, Ganglamedo, hopelessly in love with a young Han painter, is forced to marry another man. The painter and she swear to meet at a lakeside, a promise that he does not keep. Ganglamedo then disappears without a trace. Sixty years later, the young Tibetan appears in a dream to an ex-singer, An Yu, who has retrained as a sound technician after

37. Wendy Su, "Resisting cultural imperialism, or welcoming cultural globalization? China's extensive debate on Hollywood cinema from 1994 to 2007," Asian Journal of Communication, vol. 21, no. 2, 2011, pp. 186-201.

38. For example The Silent Sacred Stones (Jingiing de maneshi, 2005) by the Tibetan Wanma Caidan (Pema Tseden) and Anayi (Anayi, 2006) and So near the Sun (Yunshang taiyang, 2010) directed by Dong-Miao Chou Chou.

39. Xudong Zhang, China Modernism in the Era of Reforms, Durham, Duke University Press, 1997, p. 3.

40. Ganglamedo is the first film in a trilogy by the film-maker Dai Wei, entitled "Three Tibetan Songs" (Xizang san bu qu 西藏三部曲), the second of which was released in 2010. "Once upon a Time in Tibet" (Xizang wangshi) tells of the romance between an American pilot during the Second World War and a young Tibetan girl. The final part is set in Medieval Tibet in the Guge Kingdom. 


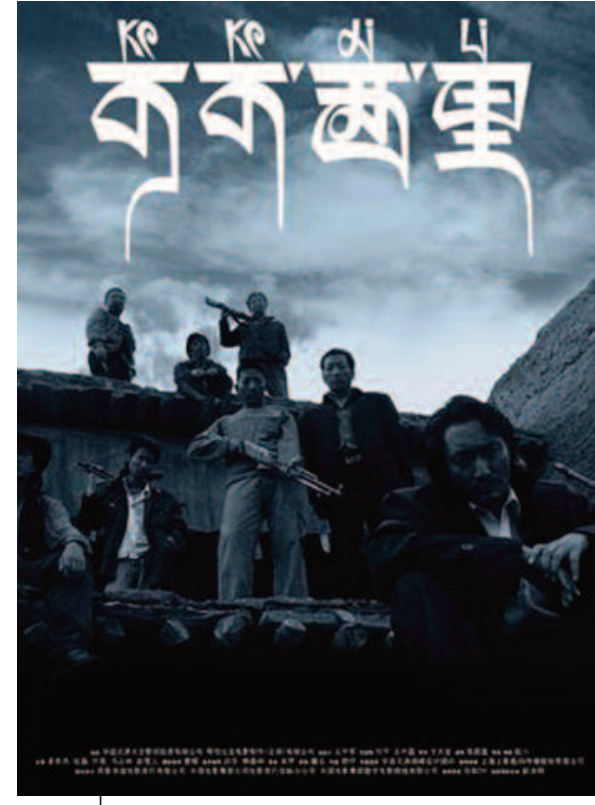

Poster for Kekexili: Mountain Patrol. Columbia Pictures, 2004. the loss of her voice. An Yu decides to go and look for Ganglamedo in Tibet, where she meets $A$ Zha, a famous drummer who lives in Lhasa. The conflicts that frequently oppose them do nothing to dampen the love they feel for each other. They finally find Ganglamedo, who has been renamed Lamu, and the Han painter who has lost his memory and who proves to be A Zha's grandfather.

The reversal of the relationships between

Han and non-Han are, at first sight, what sets contemporary representations apart from those of the 1950-1960s. On the one hand, the examples to follow are no longer those set by the Han, but by the non-Han, who have gained the power to educate or guide the Han. Moreover, the frontiers between Han and non-Han seem to be dissolving, and not only through romances and adoption, which involve the characters whatever their ethnicity. Lastly, it is worth noting that besides the eroticisation of the non-Han characters that began in the socialist films, the non-Han are represented as being extremely virile compared to the Han, who are now often made to seem childish or feminine. However, a more detailed analysis of these representations reveals that these breaks with socialist stereotypes constitute, in reality, the foundations for new myths that in fact place the Han in a dominant position again.

The relationships between Han and non-Han remain ephemeral, and the romances never come to fruition. Ruoma and A Ming, for example, gradually embark on a platonic relationship in the course of which the young Hani discovers modern objects such as the Walkman and lipstick. But their adventure comes to an abrupt end when his girlfriend comes to his studio to "make him see reason" and orders him to "rejoin his own people" in town. A Ming suddenly leaves the region, and Ruoma resumes her daily routine, disappointed but without any visible signs of rebellion. She has learnt meanwhile that any attempt to leave the village may result in physical deterioration, as demonstrated by the arrival of one of her friends, recently settled in town, who no longer has the physical strength to climb the hills previously tackled at a cracking pace. The constancy of her natural surroundings and her grandmother's songs also surpass the transient magic of the Walkman which, once the batteries are spent, no longer works. Lastly, the photography sessions stop short when a tourist, taking advantage of being in front of the camera, manipulates the young girl's body, forcing her to hold the lens of his own camera in front of her like a phallic symbol. There is a binary opposition between the modernity of the Han, seen as a source of alienation and the supposed "primitiveness" of the non-Han, celebrated as a temple of "purity," innocence, and spirituality. Progress is seen as a sign of physical and mental weakness. Introducing the non-Han to the town, modernity and outside worlds to which they are supposed to belong amounts to corrupting them physically and morally. On the other hand, it is when their experience with the non-Han is at its most intense that Huzi, who has become "half Mongol," and An Yu, who has finally found Ganglamedo, miraculously recover their voices. This redemption also marks the end of the child's stay in Tenggelitala. His father, released from prison, asks him to join him in town. An Yu also sets off back to the central region, doubtless to take up her career as a singer again. Despite the identification of Han characters with the Other, non-Han, the differences are far from being erased. On the contrary, they have once again been accentuated by the return to the Self, to the Han identity. As Kwai-Cheung Lo suggests, the concept of the "vanishing mediator," in other words an agent between two opposing ideas that intercede like a transition before disappearing, comes into its own here. ${ }^{(41)}$ The proximity to "primitive" cultures or the transformation into non-Han serves as a stepping-stone for the Han to attain a new identity. Once this is achieved, the non-Han disappear, leaving in their places the new Han, who are now fit to face the town and modernity. Esther Yau sees this "cultural disguise" as a one-way appropriation of the non-Han rather than a sharing or exchange with the Han. ${ }^{(42)}$ In practical terms, the Han remain superior in that they emerge from their experience with the non-Han even stronger, "civilised" and at the same time armed with a spirituality that ennobles them. The non-Han men admittedly also display weaknesses, in particular a propensity to alcoholism that often leads to brutality. This difficulty in controlling their emotions is seen as a source of both inspiration and danger, and contributes to placing them in an inferior position to the Han.

The sexual metaphor of the political hierarchy between Han and nonHan also poses fresh problems in contemporary films. Tibetan and Mongol men seem to dominate the Han with their "super-virility," bravery in violent combat, and ability to deal with hostile landscapes from the most arid to the snowiest, and to hunt with animal cunning. In short, they are placed in opposition to the Han, portrayed as diminished by modern, urban life and incapable of meeting their own "primal" needs. However, the depiction of male non-Han characters is remarkable both in the way they are sexualised and in their use by the Han. The excessive presence of male characters is linked to the sexual power often attributed to Tibetans and Mongols. Matthew Kapstein observes the fascination exercised by Tibetans over urban Han consumers. "Tibetan" products reputed to increase male sexual power are very common. ${ }^{(43)}$ The patrollers in Kekexili are armed to the teeth, Baruma's irresistible attraction for Shergan, and A Zha's trance when he plays the Tibetan drum, bare-chested and wearing the cowboy hat that never leaves his head, contribute to such myths. Kam Louie points out in the contemporary literature on the Oroqen the anxiety of the so-called "civilised" Han to remain strong male figures in a rapidly changing society. ${ }^{(44)}$ This attraction for the "super-virile" non-Han expresses, in the opinion of Almaz Khan, the latent desire of the Han to become one of them or, for Xueping Zhong, "the male search for a more

41. Kwai-Cheung Lo, Excess and Masculinities in Asian Cultural Productions, Albany, State University of New York Press, 2010, p. 147.

42. Esther Yau, "Is China the End of Hermeneutics?" art. cit., p. 289.

43. Matthew Kapstein, "A thorn in the dragon's side:Tibetan Buddhist culture in China," in Morris Rosabi (ed.), Governing China's Ethnic Frontiers, Seattle, University of Washington Press, pp. 230-269.

44. Kam Louie, "Masculinities and Minorities: Alienation in 'Strange Tales from Strange Lands'," The China Quarterly, no. 132, December 1992, pp. 1119-1135. 
manly image of the self." (45) Moreover, Uradyn Bulag demonstrates that gendered statements on the Han and the non-Han are above all a promotion of national unity (minzu tuanjie 民族团结). ${ }^{(46)}$ Minorities and majority are opposed and complementary in the same way as male and female are presented. The "auto-feminisation" of the Han in the face of the Mongols and Tibetans also underlines the peaceful, harmonious nature of the arrival of the Han in non-Han societies, in contrast to the violent social, economic, political, and environmental realities of the cohabitation of the minzu in the outlying areas.

Although the presence of an excessive number of non-Han women served to place Han men in a good light in the 1950-1960s, their effacement, even absence, underlines the masculinity of non-Han men in the films of the 2000s. Indeed, the vigour of the non-Han men contrasts strongly with the passivity and lack of depth of the female characters. The blandness of the character of $\mathrm{An} \mathrm{Yu}$, who is nonetheless a central figure, and the ineffectual presence of her Tibetan alter ego, Ganglamedo, serve to underline the indefatigable energy of the drummer, A Zha. Contrary to socialist films that often accord high status and key roles in economic development to women, no women are presented as a driving force in the society surrounding them. They are simply receptacles: momentarily, the active men at the centre of the story find refuge among them. Baruma embodies maternal tenderness, as well as the abnegation of a woman who endures every kind of suffering. In the case of Ruoma, the young girl is reduced to a consumer object through the commercialisation of her image. Only two women appear in Kekexili: the daughter of Ritai, Head of the Patrol, a young woman of disturbing beauty and full of consideration for the Beijing journalist; and a Han prostitute with whom one of Ritai's officers finds comfort after his expeditions in the desert. Minor elements in the film, their appearances lend nothing to the narrative apart from an erotic touch in the case of Ritai's daughter, and a quasi-maternal element in the case of the prostitute. The sale of the body is certainly not restricted to the non-Han, since the prostitute in Kekexili is Han. Nonetheless, her presence is above all to be contrasted with the daughter of Ritai. Where the Tibetan woman is concerned, a sexual nature is positive, a symbol of liberty and personal fulfilment. The sexuality of the young Han woman, on the other hand, serves here to represent a perverted society, in opposition to the "purity" of the Tibetan who, despite her obvious attraction to $\mathrm{GaYu}$, does not enter into any kind of relationship with him and preserves her integrity. Similarly, A Ming's girlfriend, whose heavy makeup and high heels are unsuited to the stony village paths, represents the material nature of Han society, whilst Ruoma preserves her natural, original nature.

The other form of reification of the non-Han in contemporary representations, just as in films of the socialist period, is the political use of their cultures and the places they live: songs, landmarks, or "traditional" processions of nonHan societies are thus inserted into propaganda discourses. The role of integrating non-Han cultural elements into the wider context of China and the rest of the world falls to the Han, either as individuals or as representatives of power. Ganglamedo demonstrates the wish to integrate Tibetan cultures into the national heritage. The film is punctuated with songs, dances, and ceremonies that the young woman carefully records. In this sense, although her approach seems personal, her action serves to symbolise the preservation of Tibetan oral traditions, which do not, however, seem at all threatened in the film. Like the question of the preservation of the Mongol way of life underlying The Paradise Plain, safeguarding the natural Tibetan environment is at first sight central in Kekexili. Based on a true story, the film voluntarily straddles documentary and fiction, blurring the boundaries between reality and imag- ination. Indeed, the obsessive fight of the patrollers to save the animals is portrayed as one that is "pure," waged by courageous and intransigent men against the essentially wicked, self-interested poachers. The simplistic opposition between the "goodies" who preserve nature and the "baddies" who destroy it leaves no room for the economic and political challenges hidden behind the ecological considerations. Moreover, the image of the Tibetans defending their native lands at the cost of their lives constitutes a metaphor that cannot be understood outside of the national context. The non-Han are the guardians of the traditions and "values" of a past that is lost or ignored by the Han, who are too busy modernising. More than the iron will to preserve their environment, the film shows the Tibetans of Kekexili devoting their energy to defending a preserve of national identity. This argument is supported by the inclusion of the Tibetan antelope of Kekexiliamongst the five mascots of the Peking Olympic Games in 2008. Under the name Yingying 迎迎, the animal represents, according to the official description, "unshakeable vitality" (wanqiang shengmingli 预强生命力) and "maximum competitive spirit" (tiaozhan jixian de jingshen 挑战极限的精神). It is also the "symbol of the extent of Chinese territory westwards" and of its "good health." (47) The film ends with the death of the patrollers in tragic circumstances but concludes with the effort made by Central Government to save the nature reserve. The reaffirmation of territorial and political unity therefore replaces the anguish of the loss of cultural and environmental heritage. In the same way, the last scene of When Ruoma was 17 shows us the photos of the young girl taken by A Ming in brochures aimed at having the Hani terraces registered as World Heritage by UNESCO. The commercial exploitation of the young non-Han is therefore justified by a project to preserve Hani cultures, although Ruoma has neither been consulted nor involved of her own free will. At work here is a unilateral desire to integrate Hani heritage into national and world heritage.

\section{Conclusion}

In the light of the preceding analyses, it can be seen that although the form of representations of the non-Han may have changed from the socialist to the contemporary era, as far as content is concerned, they have several points in common. The representations of the non-Han in these two periods of Chinese cinema although distinct, are never in opposition. On the contrary, the most recent films tend to update them. In particular, non-Han membership of a distinct spatio-temporal dimension, whether seen as negative or positive, places them at the bottom (or outside) of the social scale and under the economic and political domination of the Han. It is in these hierarchical relationships that the vision of a harmonious, yet completely inegalitarian society is reformulated. Moreover, the films of the 1950-1960s, reworked or re-released after 2000 , serve to present the socialist era as a "golden age" in modern Chinese history. The non-Han portrayed in socialist cinema are living in an auspicious era thanks to their Han "big brothers." This process contributes to the fabrication of an idealised past, symbol of prosperity and abundance in the history of China, and the anticipation of a rosy future that

45. Almaz Khan, "Who are the Mongols? State, ethnicity and the politics of representation in the PRC," in Melissa J. Brown (ed.), Negotiating Ethnicities in China and Taiwan, Berkeley, University of California, 1996, pp. 125-57. Xueping Zhong, Masculinity Besieged? Issues of Modernity and Male Subjectivity in Twentieth Century Chinese Literature, Durham, NC, Duke University Press, 2000, p. 71.

46. Uradyn Bulag, The Mongol at China's Edge, op. cit., pp. 63 sq.

47. Official website of the Games: www.beijing2008.com (consulted in January 2012).

48. Wu Jing, "Nostalgia as Content Creativity: Cultural Industries and Popular Sentiment," International Journal of Cultural Studies, vol. 9, no. 3, 2006, pp. 359-368 
is part of the socialist heritage. The films of the 2000s also endeavour to place the non-Han in a "new golden age" that looks back to an idealised past and forward to the promise of a glorious common future.

The success of socialist films in the 2000s is certainly the result of a form of nostalgia, understood as the imagined construction of a glorious past in opposition to a present seen as less rich and glorious. The socialist revolution, like the Imperial China of the Qing or the colonial Shanghai of the 1920s, is one of the historical periods most represented in contemporary productions in nostalgic terms. ${ }^{(48)}$ This nostalgia may be fed in individual fashion through personal or institutional memory, for example in the reworking and re-release of films. At the same time, films revisited in the form of television series or tourist attractions illustrate the negotiation between revolutionary heritage and the new, so-called post-socialist ideology (abandonment of class struggle to the benefit of productivism and consumerism). Lastly, these productions offer the illusion of national harmony at a time when numerous conflicts between non-Han and the central government are breaking out in Sichuan, Tibet, Xinjiang, and Inner Mongolia.

It can be seen that contemporary productions also occupy an important place for audiences abroad as well as at home. This extension beyond the frontiers obviously corresponds to the more transnational situation of the Chinese cinema industry. The exporting of contemporary films on the nonHan is very often supported by the Chinese Government. Moreover, all the films previously analysed have been rewarded and well received in international film festivals. These works illustrate the taste of Chinese and international audiences for the grandiose landscapes of the outlying regions and the dances and festivities of their populations in colourful costumes. For the Han public, the non-Han represent, as we have seen, an alternative to modernisation, urbanisation and globalisation, without opposing them for all that. Outside China, the folklore of the minority minzu resonates with the image of a traditional China - rural, rough, but also pure and infantilised. (49) It also offers an alternative to the "demonising" image of a Chinese government that is extremely oppressive towards its minorities.

The success of these films in celebrated international festivals is the sign of global agreement concerning the stereotypes that are applied to the nonHan in the case of China. This unquestioned global success can also be seen as the product of a cinema on the non-Han that is able to combine political and market constraints without the need to go beyond them. Although films on the non-Han concentrated, in the 2000s, on a certain number of individual and collective concerns and worries, they complete the task of placing the minority minzu among the ranks of consumer goods for a much wider audience. The consequence of this use of images that are as consensual as possible is that the non-Han are portrayed and represented in a contradictory manner in appearance only: as "others," strange and strangers to the world of the Han, thereby constituting aids to reflection on the Self, individual and collective identities, or as the inalienable representatives of China, when they officially represent the country in the face of international audiences. The complementary nature of this dual vision of the minority minzu contributes to maintaining the dominant ideology, attaching it to a political or market hegemony. When the non-Han are used to criticise modernity and the consumer society, this in itself creates a consumer space for an urban public who can only envisage the non-Han in the steppes, the mountains, or the desert. This is, however, to ignore the realities of urban migration, social breakdown, and the socio-economic difficulties experienced in non-Han regions. These representations of the non-Han at the dawn of the twenty-first century have had the effect of hiding the social and economic realities of their societies under the illusion of an idealised, salutary life on the margins of society. The commercialisation of the films and images of the non-Han is, in the end, merely an economic corollary to an "external" and "internal" orientalism.

Under these conditions, it is clearly difficult for contemporary film-makers to present the non-Han in less conventional ways. The same is true for films that present the darkest or most controversial aspects of Chinese society, that is to say, censorship and transmission bans. However, a parallel cinema to that disseminated by official channels does exist, and the sixth generation of Chinese film directors is representative of this. Often more dissenting, since it is directed at a less romantic vision of contemporary urban realities, it is a cinema that is not greatly interested in the non-Han. However, the non-Han communities play an economic, social, and political role in the big urban centres of China such as Shanghai, Beijing, Guangzhou, and Chongqing, and deserve the attention of the public in the same way as the Han. Nonetheless, internationally recognised directors such as Pema Tseden and Sonthar Gyal, often considered to be the pillars of Tibetan cinema, are emerging in China offering fresh perspectives that could mark a turningpoint in representations of the non-Han. ${ }^{(50)}$

It is now for future generations of film-makers, Han and non-Han alike, to defend a less conventional vision of the non-Han and to present an understanding of otherness and diversity outside the ideological lines of the Party.

\section{Filmography}

Dai Wei, Ganglamedo (Ganglameiduo), 2006, Beijing.

D Ling Zifeng, Eagles of the Steppe (Caoyuan xiongying), 1964, Beijing.

- Lu Chuan, Kekexili (Kekexili), 2004, China-USA.

- Sai Fu and Mai Lisi, Paradise Plain (Tianshang caoyuan), 2002, Inner Mongolia.

D Su Li, Third Sister Liu (Liu sanjie), 1961, Changchun.

D Tian Zhuangzhuang, Hunting Ground (Liechang zhasa), 1985, Inner Mongolia.

-, The Horse Thief (Daomazei), 1986, Xi'an.

—, Delamu (Chamagudao: Delamu), 2004, Beijing.

D Wang Jiayi, Five Golden Flowers (Wu duo jinhua), 1959, Changchun.

D Wang Weiyi, The Caravan (Shanjian lingxiang mabang lai), 1954, Shanghai.

D Wang Yi, Eagles Brave the Storm (Bao fengyu zhong de xiongying), 1957, Changchun.

D Zhang Jiarui, When Ruoma was 17 (Ruoma de shiqi sui), 2002, Beijing.

- Zhao Xinshui, Visitors on the Ice Mountain (Bingshan shang de laike), 1963, Changchun.

D Zhu Feng, A Singing Fairy (Xunzhao Liu sanjie), 2009, Guangxi.

I Translated by Elizabeth Guill.

I Vanessa Frangville is lecturer in Chinese Studies at Victoria University of Wellington (VUW), New Zealand. Email: vanessafrangville@gmail.com.

49. This is obviously an image full of paradoxes and contradictions, since China is also "the world's factory," "the biggest polluter on the planet," and "tomorrow's leading economic power," to quote just a few clichés.

50. Sebastian Veg, "Naissance du cinéma tibétain" (Birth of Tibetan Cinema), Cahiers du cinéma, June 2011, pp. 42-43. 